\title{
Supplementary Reading
}

Alda M: Genetic factors and treatment of mood disorders. Bipolar Disord 2001;3:318-324.

Angst J, Sellaro R: Historical perspectives and natural history of bipolar disorder. Biol Psychiatry 2000;48: $445-457$.

Duke P, Hochman G: A Brilliant Madness: Living with Manic-Depressive Illness. New York, Bantam Books, 1992.

Goodwin FK: Rationale for long-term treatment of bipolar disorder and evidence for long-term lithium treatment. J Clin Psychiatry 2002;63(suppl 10):5-12.

Goodwin FK, Ghaemi SN: The impact of the discovery of lithium on psychiatric thought and practice in the USA and Europe. Aust NZ J Psychiatry 1999;33:S54-S64.

Goodwin FK, Jamison KR: Manic-Depressive Illness. Oxford, Oxford University Press, 1990.

Grof P: Excellent lithium responders: People whose lives have been changed by lithium prophylaxis; in Birch NJ, Gallichio VS, Becker RW (eds): Lithium: 50 Years of Psychopharmacology. New Perspectives in Biomedical and Clinical Research. Cheshire, Weidner Publishing Group, 1999.

Grof P: Selecting effective long-term treatment for bipolar patients: Monotherapy and combinations. J Clin Psychiatry 2003;64(suppl 5):53-61. 
Jamison KR: Touched with Fire: Manic-Depressive Illness and the Artistic Temperament. New York, MacMillan, 1993.

Jamison KR: An Unquiet Mind: A Memoir of Moods and Madness. New York, Knopf, 1995.

Jamison KR: Night Falls Fast - Understanding Suicide. New York, Knopf, 1999.

Jefferson JW, Greist JH, Ackermann DL, Carroll JA: Lithium Encyclopedia for Clinical Practice, ed 2. Washington, American Psychiatric Press, 1987.

Jobnson FN: The History of Lithium Therapy. London, MacMillan, 1984.

Müller-Oerlinghausen B, Berghöfer A, Bauer M: Bipolar disorder. Lancet 2002;359:241-247.

Müller-Oerlinghausen B, Greil W, Berghöfer A (eds): Die Lithiumtherapie: Nutzen - Risiken - Alternativen, ed 2. Berlin, Springer, 1997.

Schou M: Phases in the development of lithium treatment in psychiatry; in Samson F, Adelman G (eds): The Neurosciences: Paths of Discovery II. Boston, Birkhäuser, 1992.

Woggon B: Ich kann nicht wollen! Berichte depressiver Patienten. Bern, Huber, 1998.

Wyatt RJ, Henter ID, Jamison JC: Lithium revisited: Savings brought about by the use of lithium 1970-1991. Psychiatr Q 2001;72:149-166. 